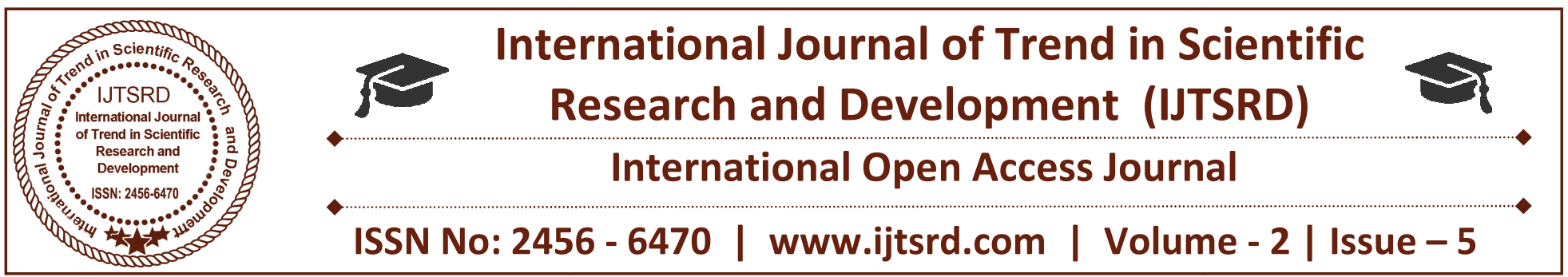

\title{
Piscicide Effects of Mahua Oil Cake from the Finfish Culture System
}

\author{
R. Vinothkumar ${ }^{1}$, Rupam Dey ${ }^{1}$, Dr. M. Srinivasan ${ }^{2}$ \\ ${ }^{1}$ Research Scholar, ${ }^{2}$ Professor \\ Center of Advanced Study in Marine Biology, Faculty of Marine Sciences, \\ Annamalai University, Parangipettai, Tamilnadu, India
}

\begin{abstract}
The present investigation envisage a study of the effects of pesticides on four fin fishes Oreochromis mossambicus from mahua oil cake, a derived from the plant Madhuca longi folia seed. Although some reports on the effects of mahua oil cake on fin fishes and Madhuca seed on fresh water pond culture systems are available, information on their effect on brackish water culture systems are rather scanty. Fishes along with the shrimps were taken at 10, 20, 30 ppt salinity and mahua oil cake (MOC) was applied at $10,15,20 \mathrm{ppm}$ concentrations to see the mortality timings of the fishes. Phyisco-chemical parameters and LC50 concentration were recorded in the study. Lethal concentration (LC50) was recorded for the species Elops machnata the concentration was found to be 5ppm. There was no variation in the temperature, although the $\mathrm{pH}$ and $\mathrm{DO}$ levels were affected by the application of MOC.
\end{abstract}

Keywords: Oreochromis mossambicus, Madhuca longifolia, mahua oil cake, phyisco-chemical parameters

\section{INTRODUCTION}

Fish predator is one problem of aquaculture farming because it can lead to bring about diseases, displacement of native species, and causes changes in the quality of the product. Similarly it can cause the decrease in population due to rise in mortality. Many plants are considered as a major source of structurally diverse biologically active compounds. Some plants contain substances of various classes that have insecticidal, piscicide and molluscicidal values, which are preferred unlike those synthetic chemical pesticides, which leave harmful residues in the aquatic environment. Plant insecticides are believed to be friendlier to the environment as they are easily biodegraded, easily available, less expensive, lower toxicity and do not leave any residues in the environment. A larger number of plant products are commonly used in controlling these unwanted fish populations such as the powdered seed of Croton tiglium and Barringtonia acutangula, tea seed cake and mahua oil cake (MOC).

Plant materials such as tea seed cake or Derris root powder, are commonly used in Japan in shrimp culture ponds to kill selectively fishes. The toxic effect of plants products of tea see cake and Derris root powder degrade within 7-12 days but Derrid root powder is not readily available throughout the world and is also expensive while tea seed cake us only available in certain parts of India. Mahua oil cake produced from Madhuca longifolia seeds after oil extraction. It contains many active ingredients mainly Saponin which represents 7.8 - 8\%. Saponin is a steroid or triterpenoids glycosides, which are a large diverse group of mainly plant derived compounds.

The mechanism of mahua oil cake is by destroying the red blood cells (RBC) leading to blood haemolysis, reducing oxygen availability for the body and this is the reason for alteration in Haemoglobin concentrations. The toxic effect of Mahua oil cake is derived from damage caused to the respiratory epithelium of gills by the detergent toxic action of the Saponin. Besides that it has destructive effects over gills of aquatic organisms. Mahua oil cake (MOC), a derivative from the plant Madhuca longifolia, is extensively used in aquaculture practices in India, both as a fish toxicant and an organic manure in fish ponds after its toxic effects are completely 
diminished. Most information regarding the effect of toxicity of MOC have been obtained through studies on the mortality rate (Laxmanan, 1983; Nath 1979). In the present communication, an attempt has been made to find out the changes in the blood parameters caused by the toxic effect of mahua oil cake. Bhatia (1970) reported that under laboratory conditions, the approximate threshold dose of MOC was $60 \mathrm{ppm}$.

However, for complete eradication of predatory and weed fishes, MOC at 200-250 ppm is recommended by the Central Inland Fisheries Research Institute (CMFRI 1968) in India. According to Laxmanan (1983), susceptibility of fishes differed with species of fish (catla, common carp, tipalia and murrel were more susceptible to the cake than rohu, mrigal, magur \& singhi etc.). Hence, Elops machnata, Anabas testudineus, Orichromis mossambicus, Arius maculatus are selected in order to compare their changes in blood values under the influence of MOC. Mahua oil cake (MOC) is the residue of Madhuca longifoli seeds after oil extraction that contains 7.8$8 \%$ of Saponin which is a toxin giving haemolysis of blood. Owing to the eradicable effectiveness of the MOC, many farmers apply it to eliminate predator fishes, shellfish or tadpoles in the fish and shrimp ponds. The effective dosage of crude saponin for eradicating predatory fishes depends on the proportion of body weight, pond's salinity level and fish species. A preliminary attempt has been made to know the effect of Mahua oil cake (MOC) in fin fishes which is locally available in TamilNadu, India.

\section{Materials and Methods}

The study was carried out on the fingerlings of Oreochromis mossambicus (total length $11.23 \mathrm{~cm}$ and weight 22.23g), Arius maculatus (channel cat fish) (total length $14.5 \mathrm{~cm}$ and weight $42.77 \mathrm{~g}$ ), Anabas testudineus (total length $7 \mathrm{~cm}$ and weight 13.12), Elops machnata (total length $5 \mathrm{~cm}$ and weight $2.5 \mathrm{~g}$ ) which were maintained for one week in plastic pools containing saline water (55ppt). Powdered mahua oil cake at the prescribed dosage $5,10,15 \mathrm{ppm}$ was applied to each of the pools and all the fishes were constantly observed to detect any visible morphological or behavioural changes due to poisoning. The experiments were performed on several separate sets. In one, control studies were made, while in others fishes were exposed to mahua oil cake. The Elops species were seen to be affected early with visible signs of poisoning and they were removed and blood tests were made after 30, 45 and
60 mins of the application of MOC. Likewise other species like Oreochromis mossambicus, Anabas testudineus, Arius maculatus were tested after 90, 120, $150 \mathrm{~min}$ of exposure to MOC.

Total erythrocyte count (TEC) was made using Neubauer's double haemocytometer and Shaw's solution as diluting fluid with 1/200 dilution in the red blood cell (RBC) pipette. Haemoglobin ( $\mathrm{Hb}$ ) concentration was estimated by acid haematin method and expressed in $\mathrm{g} / 100 \mathrm{ml}$ blood. Haematocrit (Ht) values were measured in the Wintrobe's micro haematocrit tubes filled with blood and centrifuged at $3000 \mathrm{rpm}$ for 20-25 mins. The blood smears were prepared and stained with Giemsa solution to study the shape and measurement of size of the erythrocytes of both control and treated animals. All the treated specimens were tested in distressed condition just prior to death. All the physicochemical parameters were also studied every hour using standard methods to find out any possible changes which might affect the species. To make an uniform comparison between the control and treated values, only females of both the species were selected.

\section{Preparation of mahua oil stock solution}

Commercially available mahua oil cake was purchased from a local shop located in Parangipettai. The cakes were soaked in saline water for 3-5 days and the excess oil was discarded and the cakes were exposed to sunlight for drying completely. Now the cakes were powered finely and 1 gram of this powder was weighed in an electronic balance and dissolved in 1 litre of $30 \mathrm{ppt}$ saline water. The solution was allowed to rest overnight (12-15 hours). $100 \mathrm{ml}$ of this solution was taken in a container of 50 litre capacity and mixed thoroughly with 20 litres of $30 \mathrm{ppt}$ saline water. Now the stock solution of mahua for application in the tanks was ready. Then, in three different beakers, three different concentration of mahua stock solution was taken viz.5, 10 and 15ppm and used in the tanks of different salinity.

\section{Results}

Assessment of physic-chemical characteristics such as temperature, $\mathrm{pH}$ and dissolved oxygen level and toxicity test are mentioned below:

\section{Elops machnata}

Mortality was observed at $5 \mathrm{ppm}$ of Mahua oil cake at 10ppt salinity in 1 hour 20 minutes while in 10ppt salinity at the concentrations of $10 \mathrm{ppm}$ and $15 \mathrm{ppm}$ of 
International Journal of Trend in Scientific Research and Development (IJTSRD) ISSN: 2456-6470

the Mahua stock solution the mortality occurred in 1 Elops machnata the concentration was found to be hour and 40 minutes respectively. The lethal 5ppm. The results are given in table number 1. concentration (LC50) was recorded for the species

1. DETAILS OF THE EXPERIMENT 1 AND ITS RESULT

\begin{tabular}{|c|c|c|c|c|c|c|}
\hline Species & $\begin{array}{c}\text { Dosage of } \\
\text { MOC }(\mathbf{p p m})\end{array}$ & $\begin{array}{c}\text { Temp. range } \\
\left(\mathbf{0}^{\mathbf{0}} \mathrm{C}\right)\end{array}$ & $\begin{array}{c}\text { DO range } \\
(\mathrm{ml} / \mathrm{lit})\end{array}$ & $\begin{array}{c}\mathrm{pH} \\
\text { range }\end{array}$ & $\begin{array}{c}\text { Salinity } \\
\text { range }(\mathrm{ppt})\end{array}$ & $\begin{array}{c}\text { Mortality time } \\
\text { (hours/minutes) }\end{array}$ \\
\hline \multirow{2}{*}{$\begin{array}{c}\text { Elops } \\
\text { machnata }\end{array}$} & 5 & 32 & 4.7 & 7.6 & 10 & $1 \mathrm{hr} .20 \mathrm{~min}$. \\
\cline { 2 - 7 } & 10 & 32 & 3.2 & 7.5 & 10 & $1 \mathrm{hr}$. \\
\cline { 2 - 7 }
\end{tabular}

\section{Duration ofmortality}

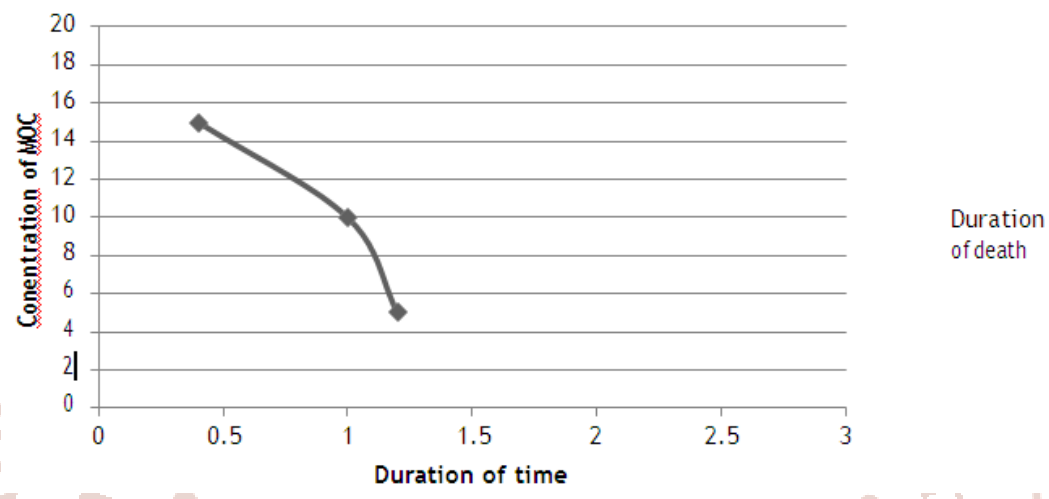

The mortality occurs for Elops machnata between 0 hours to 2 hours after the application of MOC

\section{Oreochromis mossambicus}

Mortality was determined for various concentration of I concentration (LC50) was recorded for the species Mahua oil cake i.e. 5, 10 and 15 ppm at 20ppt salinity was found to occur at 18 hours, 7 hours 50 minutes and 5 hours 45 minutes respectively. The lethal Oreochromis mossambicus the concentration was found to be $15 \mathrm{ppm}$. The results are given in table number 2 .

\section{DETAILS OF THE EXPERIMENT 2 AND ITS RESULT}

\begin{tabular}{|c|c|c|c|c|c|c|}
\hline \multirow{2}{*}{ Species } & $\begin{array}{c}\text { Dosage of } \\
\text { MOC }(\mathbf{p p m})\end{array}$ & $\begin{array}{c}\text { Temp. range } \\
\left(\mathbf{0}^{\mathbf{0}} \mathrm{C}\right)\end{array}$ & $\begin{array}{c}\text { DO range } \\
(\mathrm{m} / \text { /it) }\end{array}$ & $\begin{array}{c}\text { pH } \\
\text { range }\end{array}$ & $\begin{array}{c}\text { Salinity } \\
\text { range }(\mathrm{ppt})\end{array}$ & $\begin{array}{c}\text { Mortality time } \\
\text { (hours/minutes) }\end{array}$ \\
\hline \multirow{2}{*}{$\begin{array}{c}\text { Oreochromis } \\
\text { mossambicus }\end{array}$} & 5 & 34 & 4.3 & 7.7 & 20 & $18 \mathrm{hr}$. \\
\cline { 2 - 7 } & 10 & 34 & 3.1 & 7.5 & 20 & $7 \mathrm{hr} .50 \mathrm{mins}$. \\
\hline
\end{tabular}

Duration of mortality

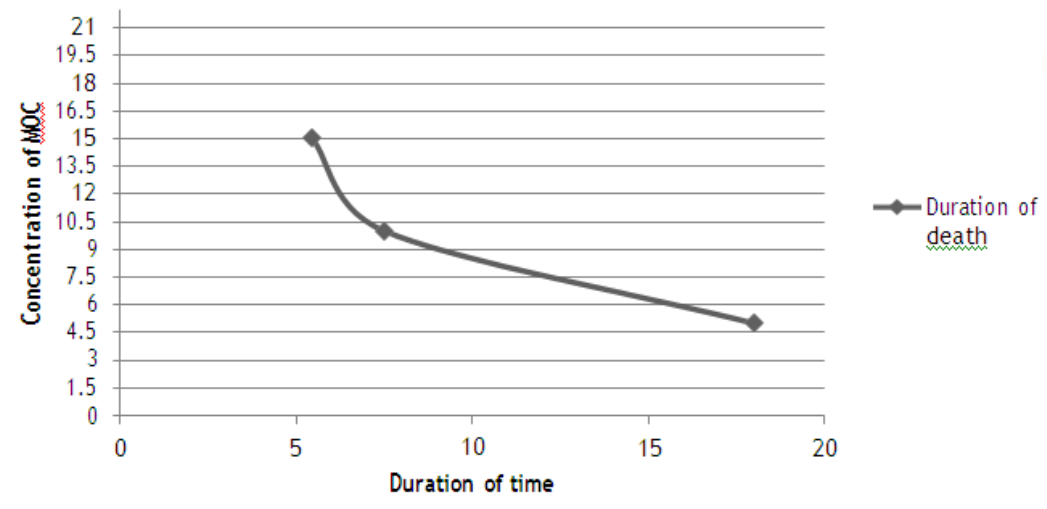


The mortality occurs for Orechromis mossambicus between 0 hours to 18 hours after the application of MOC

\section{ANABAS TESTUDINEUS}

The toxic effect of MOC was made at 20ppt salinity at three different concentrations i.e. 5, 10 and $15 \mathrm{ppm}$ and mortality was found to occur at 1 hour 50 minutes, 1 hour 30 minutes and 55 minutes respectively. The lethal concentration (LC50) was recorded for the species Anabas testudineus the concentration was found to be $15 \mathrm{ppm}$. Details are given in table 3.

\section{DETAILS OF THE EXPERIMENT 3 AND ITS RESULT}

\begin{tabular}{|c|c|c|c|c|c|c|}
\hline Species & $\begin{array}{l}\text { Dosage of } \\
\text { MOC (ppm) }\end{array}$ & $\begin{array}{c}\text { Temp. range } \\
\left(0^{0} \mathrm{C}\right)\end{array}$ & $\begin{array}{l}\text { DO range } \\
(\mathrm{m} / / \mathrm{lit})\end{array}$ & $\begin{array}{l}\mathrm{pH} \\
\text { range }\end{array}$ & $\begin{array}{l}\text { Salinity } \\
\text { range (ppt) }\end{array}$ & $\begin{array}{l}\text { Mortality time } \\
\text { (hours/minutes) }\end{array}$ \\
\hline \multirow{3}{*}{$\begin{array}{c}\text { Anabas } \\
\text { testudineus }\end{array}$} & 5 & 34 & 4.3 & 7.7 & 20 & $1 \mathrm{hr} .50 \mathrm{mins}$. \\
\hline & 10 & 34 & 3.1 & 7.5 & 20 & $1 \mathrm{hr} .30 \mathrm{mins}$. \\
\hline & 15 & 34 & 2.3 & 7.3 & 20 & 55 mins. \\
\hline
\end{tabular}

\section{Duration of mortality}

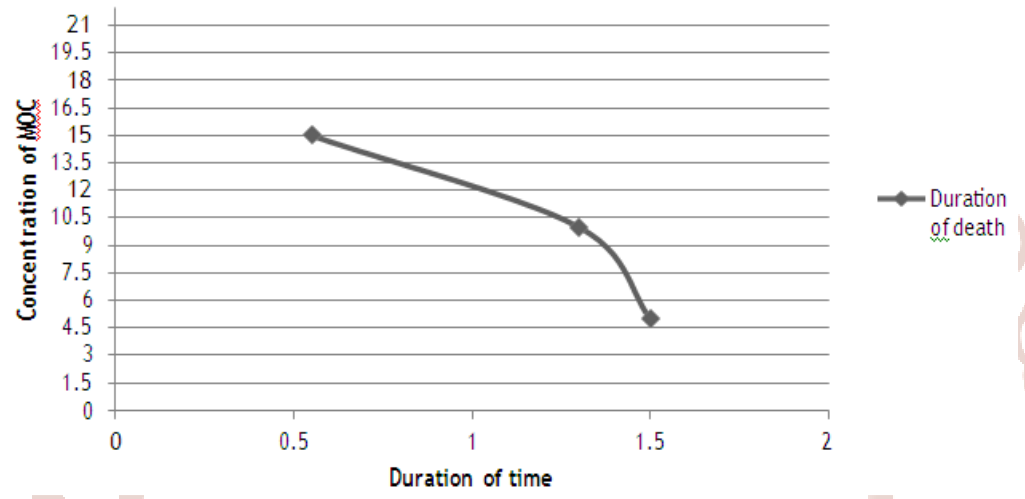

The mortality occurs for Anabas testudineus between 0 hours to 1 hours and 50 minutes after the application of MOC

Arius maculatus

Toxicity level was determined with 30ppt salinity and mortality was found to occur around 1 hour 40 minutes, 1 hour 15 minutes and 45 minutes for the concentrations 5, 10 and $15 \mathrm{ppm}$ respectively. The lethal concentration (LC50) was recorded for the species Arius maculatus the concentration was found to be $10 \mathrm{ppm}$. Details are given in table number 4 .

\section{DETAILS OF THE EXPERIMENT 4 AND ITS RESULT}

\begin{tabular}{|c|c|c|c|c|c|c|}
\hline Species & $\begin{array}{c}\text { Dosage of } \\
\text { MOC }(\mathbf{p p m})\end{array}$ & $\begin{array}{c}\text { Temp. range } \\
\left(\mathbf{0}^{\mathbf{0}} \mathrm{C}\right)\end{array}$ & $\begin{array}{c}\text { DO range } \\
(\mathbf{m l} / \mathbf{l i t})\end{array}$ & $\mathrm{pH}$ range & $\begin{array}{c}\text { Salinity } \\
\text { range }(\mathrm{ppt})\end{array}$ & $\begin{array}{c}\text { Mortality time } \\
\text { (hours/minutes) }\end{array}$ \\
\hline \multirow{2}{*}{$\begin{array}{c}\text { Arius } \\
\text { maculatus }\end{array}$} & 5 & 35 & 4.5 & 7.4 & 30 & $1 \mathrm{hr} .40 \mathrm{mins}$. \\
\cline { 2 - 7 } & 10 & 35 & 3.4 & 7.4 & 30 & $1 \mathrm{hr} .15 \mathrm{mins}$. \\
\cline { 2 - 7 } & 15 & 36 & 2.6 & 7.1 & 30 & 45 mins. \\
\hline
\end{tabular}

Duration of mortality

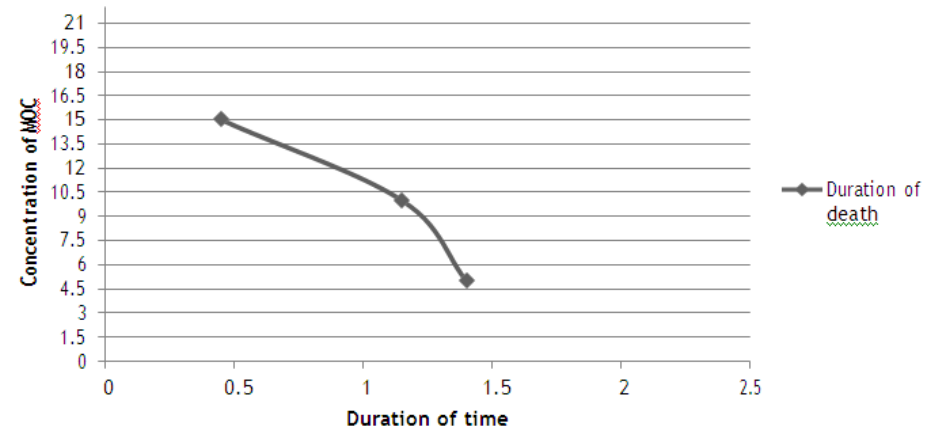

The mortality occurs for Arius maculatus between 0 hours to 18 hours after application of MOC 
The colour of the water showed a change after the addition of MOC at higher concentrations. The reason is still unknown and needs through research also formation of a frothy layer was seen.

In addition to the mortality, the fishes on exposure to the MOC stock solution showed an increased rate of excretion and released more mucus in high concentration treatment. The fishes that merely died had opaque body colour compared to the normal fishes and slow respond and movement was observed. For those of the mortality experiencing fishes, no movement of fin or operculum was seen and they were observed at the bottom of the tanks.

The respond is in agree with El-Murr et al 2014, that is likely due to reflection increase of oxidative stress that showed revealed normocytic, normochromic anaemia and significantly increased level of SOD and CAT activities. The damage of general tissues of various organs was also detected with high dosage of Mahua oil cake (MOC).
Temperature and $\mathrm{pH}$ in all the treatments are not different before and after tests, meanwhile dissolved oxygen showed optimum level before the test and decreasing later after the test. Nevertheless, these parameters are not likely a cause of mortality of Climbing perch (Anabas testudineus) and Channel cat fish (Arius maculetus), because these fish can thrive well in deficient dissolved oxygen waters. Moreover it has better ability of breathing due to its special organs and tolerance of adverse environments. For this reason the fish mortality in the experiment is more likely caused by MOC toxicity.

However another test was carried out for DO depletion since it's a serious issue in shrimp culture. The MOC not only killed the fish at different concentrations but severe decrease in the DO level was observed which can be proven harmful for a successful aquaculture practice. (Table 5)

\section{TEMPRATURE, $\mathrm{pH} \&$ DISSOLVED OXYGEN LEVELS BEFORE AFTER TOXICITY TEST}

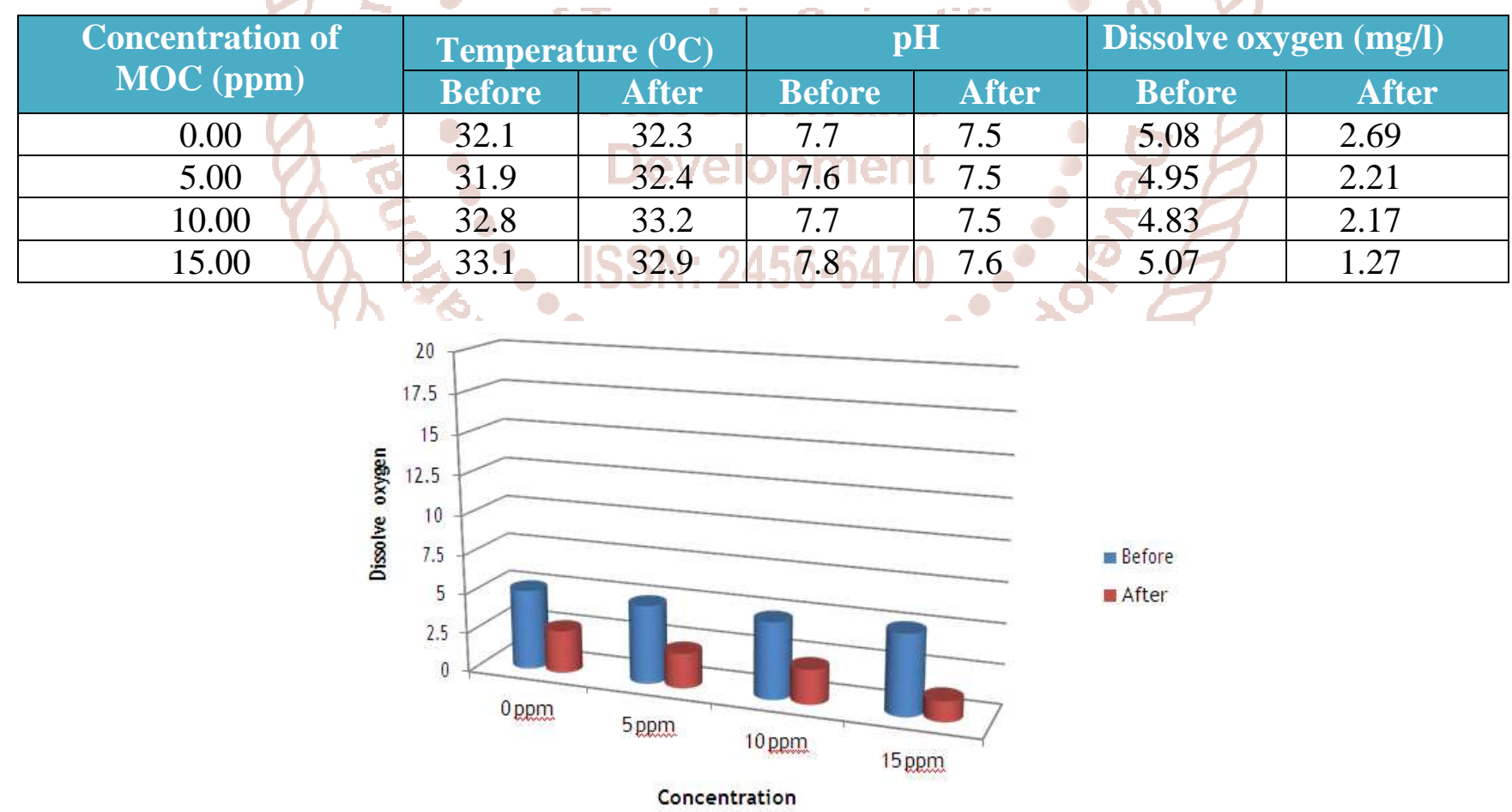

\section{Graphical representation of Variation of dissolve oxygen in water before and after application of MOC}

Due to the application of MOC, it was observed that the fishes depicted some behavioural changes like gulping, surfacing and sluggish movement. Although on reaching mortality fishes are observed, mainly at the bottom of the tank. 
Elops machnata were captured at a very preliminary stage and therefore mortality was observed at an earlier rate compared to the rest of the fishes, while the tank containing Arius (which was more than a fingerling size) portrayed more consumption of time for death. Then the death of Anabas species was observed. Lastly Oreochromis, being quite a good sized fish $(15 \mathrm{~cm})$ took maximum time to show mortality.

\section{Cytological observation}

The prepared blood smear was observed under microscope at 40x power and it was observed that there were some changes in the structure of $\mathrm{RBC}$ pre and post treatment of MOC (Fig 8).Healthy RBC with entire cell wall was observed in case of normal blood smear, while the MOC treated fishes had somewhat ruptured $\mathrm{RBC}$ which showed the possible cause of death, i.e. haemolysis.

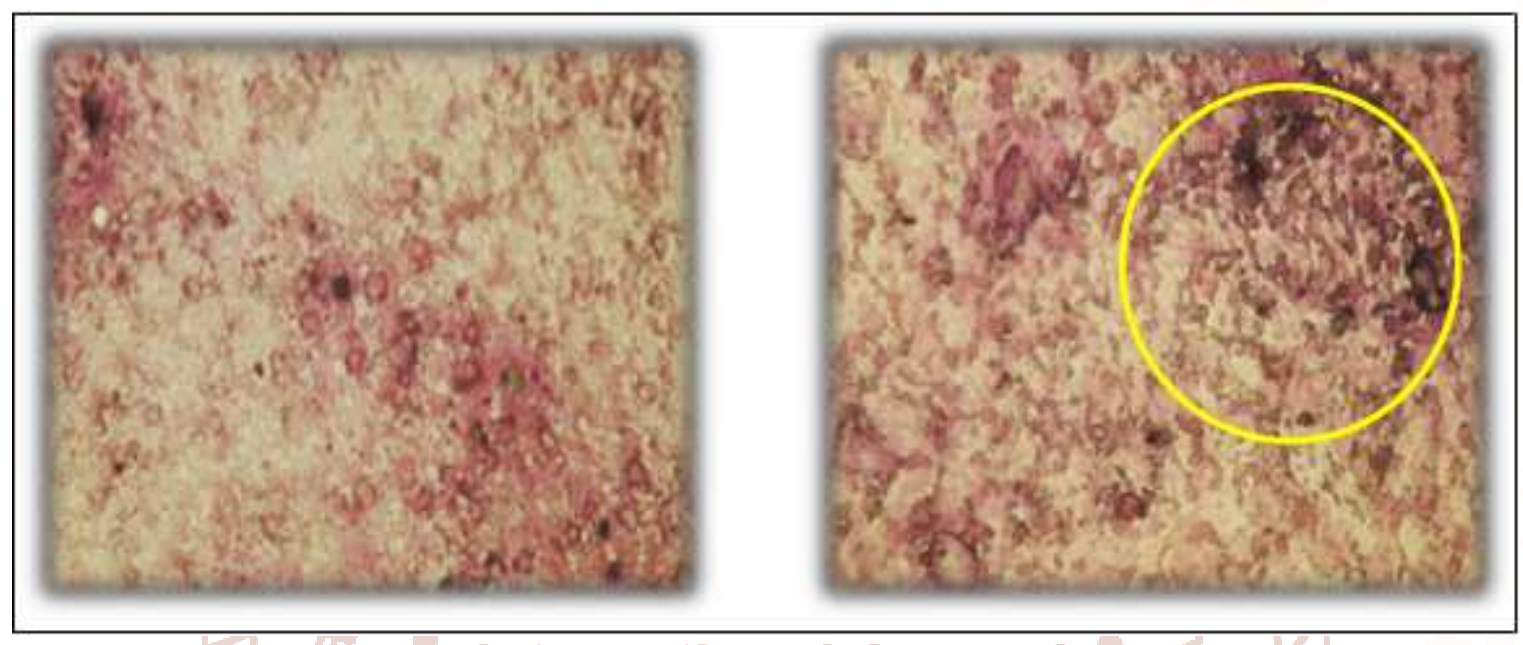

(a)

(b)

Fig 8: Microscopic view of $\mathrm{RBC}$ before (A) and after (B) treatment with MOC showing rupture in the blood cells

Blood sample was procured from all the four fishes and one common thing that was observed is the rupture of RBC which shows haemolysis or haemolytic activity in the blood cells of the fishes as depicted in the above picture.

\section{Discussion}

Fish predator is one of the major problems of aquaculture because it can lead to bring about diseases, displacement of native species ad causes changes in the quality of the product. So, the eradication of these fishes fish toxicants are use. Fish toxicants can be grouped into plant derivatives, chlorinated hydrocarbons, organo-phosphates.

Chlorinated hydrocarbons are the most stable and toxic compounds, not metabolised and remain stored in fish tissues. While plant piscicides are believed to be friendlier to the environment, as they are easily biodegraded, easily available, less expensive, lower toxicity and do not leave any residue in the environment.

Sumit Homechaudhury et al.(1986), studied the effect of Mahua oil cake on the blood cells and blood values of Heteropneustes fossilis and Cyprinus carpio where the haematological indices of these fishes were studied after being treated with mahua oil cake, and reported gradual and complete shrinkage of erythrocytes followed by ultimate haemolycis. While Vishal Rajput and Richa Gaur (2015), reported on the toxicological studies of croton and mahua extracts on walking cat fish Clarius batrachus. The reported protein changes in muscle, liver and intestine and found remarkable protein fluctuations.

El-Murr et al. (2014), presented studies on molecular, biochemical and histological effect of Tea seed cake on different organs of Oreochromis niloticus. The result revealed that normocytic, normochromic anaemia with significant increase in the levels of SOD and CAT activity and gene expression that reflects oxidative stress. Also, acute toxicity of Tea seed cake on Climbing perch Anabas testudineus for controlling of fish predator which has Accessory Respiratory Organs (ARO), for farming application.

In the present study the acute toxicity level of mahua 
oil cake was checked over the predatory fishes Oreochromis mossambicus, Arius maculatus (channel cat fish), Anabas testudineus, Elops machnata and also the water quality parameters such as temperature, $\mathrm{pH}$ and dissolve oxygen levels were monitored before and after application of MOC.

From the above experiment, it was observed that in addition to mortality, the fishes on exposure to MOC showed increase rate of excretion and released more mucus at high concentration. Temperature and $\mathrm{pH}$ in all the treatments (high and low concentration) are not different before and after application, meanwhile the DO level showed optimum decrease when subjected to higher concentration.

Hence, it can be recommended that the usage of MOC can be carried out in culture ponds but at limited concentration.

\section{Acknowledgments}

The authors wish to thank the Dean and Director of CAS in Marine Biology and authorities of Annamalai University for providing facilities.

\section{References}

1. Bhatia H L, 1970, Use of mahua oil cake in Fishery management. Indian Farming 20,pp-3940

2. Boyd C L, 1990, Water quality in ponds for aquaculture. Dirminghum Publishing Co., Dirminghum, AL, pp- 482

3. CMFRI 1968, report of the Central Inland Fisheries Research Institute, Barrackpore

4. El- Murr A, Ali HA ad Eldeen, N. A. M. N 2014. Molecular, biochemical and histological effects of tea seed cake on different organs of Oreochromis niloticus. Global veterinaria, 13(5), pp711-719

5. Istvan, 2000, U. Semi natural products and related substances as alleged botanical pesticides, pest management science. 56: pp 703-705

6. Kittima, M, Rahaman M M, Bashar A, Hasan N, Ahmed F and Hossain Y.; 2013, Effect of stocking density on survival, growth and production of Thai climbing perch (Anabas testudineus) under fed ponds. Sains Malayasiana 41(10), pp 12051210

7. Lakshman A K. 1983, Mahua oil cake in fish culture. Environ.Ecol 1, pp-163-167
8. Marston A Hostettmann K.; 1985. Plant molluscicide. Phytochemistry 24: pp 639- 652

9. Nath D.; 1979, toxicity of mahua oil cake under laboratory and field conditions; in symposium on inland aquaculture (Abstracts), February, 12-14 CIFRI, Barrack pore

10. Roy P. K and Munshi J.P.; 1989. Effect of saponin extracts on oxygen uptake haematology of air breathing climbing perh, Anabas testudineus (Bloch). J. Freshwater Biol., 1, pp167-172 